\title{
Woody species associated with coffee production systems in southern Colombia
}

\author{
Especies leñosas asociadas a los sistemas productivos de \\ café en el sur de Colombia
}

\begin{abstract}
Héctor Ramiro Ordóñez-Jurado¹; Dayana Liseth Martínez²; Marbel Cerón Martínez ${ }^{3}$
\end{abstract}
\begin{abstract}
ARTICLE DATA
Research professor, PhD, Universidad de Nariño, San Juan de Pasto, Nariño, Colombia, hectoramiro@ hotmail.com

2 Agroforestry Engineer, Universidad de Nariño, San Juan de Pasto, Nariño, Colombia, dalimaor.dmn@ gmail.com

Agroforestry Engineer, Universidad de Nariño, San Juan de Pasto, Nariño, Colombia, benavidesurbano14@gmail.com
\end{abstract}

Citar: Ordoñez-Jurado, H.; Martínez, D.; Cerón, M. (2021). Woody species associated with coffee production systems in southern Colombia. Revista de Ciencias Agrícolas. 38(1): 4-16.

doi:https://doi.org/10.22267/rcia.213802.155

Received: October 102020.

Accepted: May 072021.

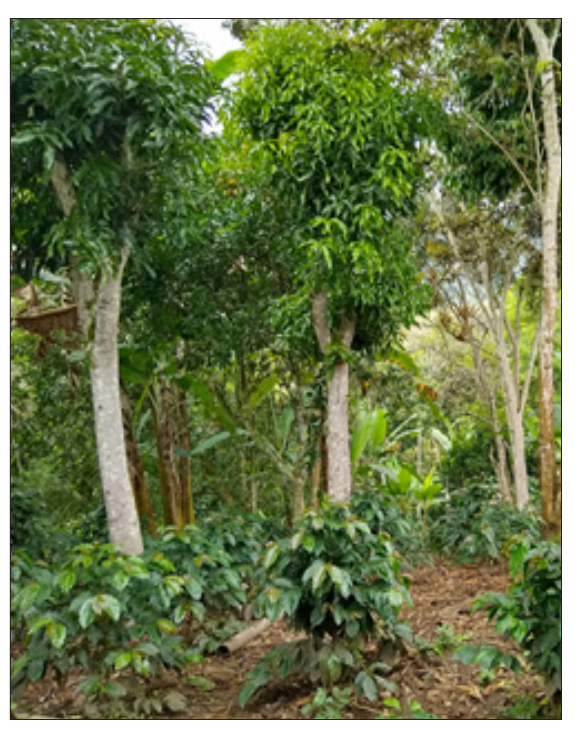

\section{ABSTRACT}

In the coffee zone of the town La Unión- Nariño, native or introduced trees are associated with the productive systems of the farms, mainly because they provide shade for coffee crops, where particular aspects such as species biodiversity and silvicultural management are unknown. With the aim of knowing the woody species of common use and the cultural importance, a semi structured survey was applied to 100 coffee growers who were selected at random and aleatorily distributed in three altitudinal ranges: (m a.s.l.): I (<1500), II (1500-1800) and III (> 1800). Species richness was determined for each chosen range; for diversity between ranges, the Jaccard Index (JI) and the Cultural Importance Index (CI) were used. The latter was determined by adding up the intensity of use (IU), frequency of citation (FC), and use value (UV). In the three altitude ranges evaluated, 59 tree species were found. These were distributed in 32 botanical families and 46 genera. The fabaceae family was the most representative, followed by rutaceae, myrtaceae and bignoniaceae; $45.8 \%$ of the species were introduced. Among the altitudinal ranges, a low degree similarity was found; ranks I and II shared 24 species, which is equivalent to $33.8 \%$ of their floristic composition. As for ranges I and III, they had an even lower degree of similarity: $24.2 \%$; only 17 species were shared. The species I. densiflora had the highest percentage of CI, with 32.92\%, followed by $C$. sinensis with $31.98 \%$; then the species T. gigantea and $P$. americana with $30.49 \%$ and $26.27 \%$ respectively. These species were of great importance to coffee growers due to the positive impact they have on the family economy and their contribution to the environmental wellbeing of production systems.

Keywords: tree; biodiversity; wealth; similarity; somber.

\section{RESUMEN}

En la zona cafetera del municipio de La Unión Nariño, los árboles nativos o introducidos, se asocian a los sistemas productivos de las fincas, especialmente como sombra del cultivo del café, en donde se desconoce aspectos particulares como la biodiversidad de especies y 
manejo silvicultural. Con el objetivo de conocer las especies leñosas de uso común y la importancia cultural, se aplicó una encuesta semiestructurada a 100 productores seleccionados aleatoriamente y distribuidas proporcionalmente en tres rangos altitudinales: I (<1500 msnm), II (1500-1800 msnm) y III (> $1800 \mathrm{msnm}$ ). Se determinó la riqueza de especies a nivel de rango, para la diversidad entre rangos, se utilizó el Índice de Jaccard (IJ) y el Índice de importancia cultural (IC), el cual se determinó mediante la sumatoria de la intensidad de uso (IU), frecuencia de mención (FM) y valor de uso (VU). En los tres rangos altitudinales evaluados, se encontraron 59 especies arbóreas, distribuidas en 32 familias botánicas y 46 géneros, la familia fabaceae fue la más representativa, seguida por rutaceae, myrtaceae y bignoniaceae; el 45,8\% de las especies son introducidas. Entre los rangos altitudinales existe baja similitud, donde los rangos I y II, comparten 24 especies, equivalente al 33,8\% de su composición florística; los rangos I y III, presentan una menor similitud con un 24,2\%, comparten 17 especies. La especie I. densiflora presentó el mayor valor en porcentaje del ICC, con un 3,92\%, seguida por $C$. sinensis con $31.98 \%$; a continuación, las especies T. gigantea, y P. americana con $30,49 \%$ y $26,27 \%$ respectivamente. Las especies identificadas son de gran importancia para los productores, puesto que genera impactos positivos en la economía familiar, y contribuyen al bienestar ambiental de los sistemas productivos.

Palabras clave: árbol; biodiversidad; riqueza; similitud; sombrío.

\section{INTRODUCTION}

Colombia is the first soft coffee producer in the world with Coffea arabica L., which has different varieties: Typica, Bourbon, Caturra, Maragogipe, Colombia, Cenicafé 1 and Castillo. By 2020, the area used for coffee production was 844.000 ha, and the department of Nariño contributed with 35.760; this represents $4.24 \%$ of the national total. According to the National Federation of Coffee Growers of Colombia (FNC for its initials in Spanish) (FNC, 2020; FNC, 2014) and Red de información y comunicación del sector Agropecuario Colombiano (MADR, 2017), about 4 million Colombians depend financially on this crop. The largest coffee growing areas are located in northern municipalities; one of them is La Unión, where one of the best quality coffees is produced. This coffee is highly appreciated internationally due to its denomination of origin (Martínez, 2004; Oberthür et al., 2011).

There exists a great number of woody species which can be used to provide direct shade to coffee or as part of the shrubbery in farms. These species, despite their potential, have been deemed to be endangered or at risk of extinction in our country (Farfán, 2012). In Nariño, in most farms, woody species are of primary importance in the structure and function of coffee productive systems. These species are associated with coffee growing, border setting up, living fences, scattered trees, alley cropping, and windbreakers; fruit species are prioritized for self-consumption or for sale, as the fruit may be used for multiple purposes (Ordoñez, 2014; Farfán and Mestre, 2013).

The area selected for this study stands out for its diversity in terms of flora, which is of vital importance for shade-grown coffee and other productive systems under different agroforestry arrangements. Most woody species are native to the region or geographical areas with similar features. The ones that are most commonly used as shade vegetation are Inga and fruit trees such as orange trees Citrus sinensis and lemon trees Citrus limon. In this sense, coffee growers tend to select native vegetation due to financial, environmental, and usability reasons (Garen et al., 2009; Muñoz and Villota 2014; Escobar et al., 2016). 
Determining the cultural importance of woody species in coffee systems is a priority; as Turner (1988) states, it is necessary to establish the importance value of species unbiasedly. We need to assess their cultural importance based on a score obtained from the addition of the factors that contribute to their importance; the value of tree species is obtained by using the importance value index or use value (Da Silva et al., 2006).

This study assessed floral diversity and cultural importance of tree species in coffee systems established in La Unión (Nariño). To meet this purpose, it was necessary to analyze the perceptions and knowledge of local coffee growers regarding the importance of trees in their farms. The data collected provides information that comprises the uses and preservation of woody species as a strategy for sustainable development.

\section{MATERIALS AND METHODS}

The study was conducted in the municipality of La Unión, department of Nariño, located at an altitude between 900 and $2200 \mathrm{~m}$ a.s.l. The average temperature is $19^{\circ} \mathrm{C}$; annual precipitation is $2116 \mathrm{~mm}$; average sunlight 4,9 hours/day. La Unión is located at 136 and $06^{\prime \prime}$ North latitude and 7700 ' and 15" West longitude (Alcaldía municipal La Unión, 2012). In this municipality, shallow volcanic soil prevails. This type of soil has a low content of organic matter and medium natural fertility, and it is highly prone to erosion (Gómez et al., 1991).

In order to identify the most commonly used woody species, which have cultural importance in coffee production systems, it was necessary to select the farms that would be part of the study.
To do so, the information provided by Comité de Cafeteros de Nariño - La Unión (2018) was used. This committee reports 6187 coffee farms, which cover an area of 5087 ha. The sample population is made up of coffee farms that are located in three altitudinal ranges: <1.500, $1.500-1.800$ and $>1.800 \mathrm{~m}$ a.s.l.

In this research, a simple random sampling was used, taking coffee farms as population and each coffee farm as sampling unit. At the same time, each sampling unit was taken as an analysis unit, assuming a margin of error at $10 \%$, and a 95\% confidence. To establish the sample size and considering that the study deals with a finite population, Murray and Larry's (2005) formula was used.

$$
n=\frac{Z_{\alpha \cdot N \cdot p \cdot q}^{2}}{i^{2}(N-1)+Z_{\alpha \cdot p \cdot q}^{2}}
$$

where:

n: simple size

$\mathrm{N}$ : population size

z: value corresponding to gauss distribution, $\mathrm{z} \alpha=0.05=1.96$

p: expected prevalence, q: $1-p$ (if $p=70 \%$, $q=30 \%)$

i: $\quad$ margin of error $10 \%, i=0.1$

It was also necessary to collect secondary data related to Plan de Ordenamiento Territorial (POT for its initials in Spanish), a land-use plan; a survey administered to coffee growers; and studies conducted in the area by public and private institutions related to the coffee sector.

To collect primary information, a semistructured interview was designed. The questions included some related to the woody species that prevail in the area, emphasizing their local name, uses, and importance in a farm. 
These are telltale indicators of the possible management strategies coffee growers employ. The survey was administered to 1000 coffee growers who were randomly selected. This instrument was proportionally applied in the three altitudinal ranges.

The information gathered through the surveys was analyzed to later create a database; useless or redundant information was eliminated. The databases of the herbarium of Universidad de Nariño, the online herbarium of Tropicos (2021), and that of the Universidad Nacional de Colombia (2020) were used to identify the woody species present in coffee farms.

The number of species was established to have a clear idea of the richness of species in each altitudinal range. Additionally, the Jaccard Index (JI), which measures similarities across ecosystems, was used to determine the degree of diversity across altitudinal ranges (Finol, 1971).

$$
\mathrm{JI}=\mathrm{j} / \mathrm{a}+\mathrm{b}-\mathrm{j}
$$

Where: (a): number of species present in ecosystem A; (b): number of species present in ecosystem B; (j) number of species shared by the communities.

The Cultural Importance Index (CI) was calculated by adding up the intensity of use (IU), the frequency of citation (FC), and use value (UV) (Sánchez et al., 2017). The equations used were as follows:

$$
\begin{gathered}
\text { IU }=\frac{\text { Number of uses of Sp. } \mathrm{x}}{\text { Overall number of uses for all species }} * 100 \\
\mathrm{FC}=\frac{\text { Number of citations of sp. } \mathrm{x} \text { for all the uses }}{\text { Overall number of citations of all the species for all the uses }} * 100 \\
\mathrm{UV}=\frac{\text { Number of citations of sp. } \mathrm{x} \text { for one use }}{\text { Overall number of citations of all the species for one use }} * 100
\end{gathered}
$$

$$
\begin{gathered}
\mathrm{UVt}=\sum(\mathrm{UVx}+\mathrm{UVy}+\mathrm{UVz}+\cdots \ldots \mathrm{UVn}) \\
\mathrm{CI}=\frac{(\mathrm{IUz}+\mathrm{FCz}+\mathrm{UVtz})}{300}
\end{gathered}
$$

Where: Intensity of use (IU): percentage of uses in which one species appears; frequency of citation (FC): sum of citations of one species, all the uses, and all the informants; use value (UV): percentage of uses in which a species appears for a given use according to the categorical classification of use.

In determining the cultural importance index, the following categories of use were found: Wood, firewood, charcoal, poles, protective reforestation, erosion control, soil protection, ornamental uses, fruit, green manure, rituals, medicine, domestic animal and wildlife food, living fence, silvopasture, animal protein (Pp), association with crops, food, handicrafts, sawmilling, coloring, construction, housing construction, treatment and prevention of psychotropic diseases, toxins, and others including species with specific uses.

The primary information and that obtained through surveys was processed using Microsoft Excel 2010.

\section{RESULTS AND DISCUSSION}

Fifty-nine tree species of common use that interact with coffee crops were found in the three altitudinal ranges chosen for this study. These species were distributed into 32 plan families and 46 genera (Table 1). The fabaceae family was the one that stood out the most with 11 species. This was followed by rutaceae with 7 , then by myrtaceae and bignoniaceae with 4 species each, and lauraceae with 3 species (Table 1). 
Table 1. Species identified in three altitudinal ranges in the municipality of La Unión - Nariño.

\begin{tabular}{|c|c|c|}
\hline Common name & Scientific name & Family \\
\hline Acacia negra & Acacia melanoxylon R. Br. & Fabaceae \\
\hline Achiote & Bixa orellana; L & Bixaceae \\
\hline Aguacate & Persea americana; Mill & Lauraceae \\
\hline Aguacatillo & Persea caerulea; (Ruiz \& Pav.) Mez & Lauraceae \\
\hline Arrayan & Myrcianthes rhopaloides (Kunth) McVaugh & Myrtaceae \\
\hline Balso & Ochroma pyramidale; (Cav. ex Lam.) Urb. & Malvaceae \\
\hline Cacao & Theobroma cacao L. & Malvaceae \\
\hline Cachimbo & Erythrina poeppigiana (Walp.) O.F. Cook. & Fabaceae \\
\hline Cajeto or crecedor & Delostoma integrifolium D. Don & Bignoniaceae \\
\hline Carambolo & Averrhoa carambola; $\mathrm{L}$ & Oxalidaceae \\
\hline Carbonero gigante & Albizia carbonaria Britton & Fabaceae \\
\hline Cascarillo & Cinchona pubescens Vahl & Rubiaceae \\
\hline Cedro & Cedrela odorata L. & Meliaceae \\
\hline Chachafruto & Erythrina edulis Triana ex Micheli. & Fabaceae \\
\hline Chilco & Escallonia paniculata (Ruiz \& Pav) & Escalloniaceae \\
\hline Chirimoya & Annona cherimola; Mill., Gard & Annonaceae \\
\hline Ciprés & Cupressus lusitanica; Miller & Cupressaceae \\
\hline Cordoncillo & Piper aduncum L. & Piperaceae \\
\hline Cucharo & Myrsine guianensis (Aubl.) Kuntze & Myrsinaceae \\
\hline Eucalipto & Eucalyptus globulus; Labill & Myrtaceae \\
\hline Gualanday & Jacaranda caucana; & Bignoniaceae \\
\hline Guamo churimba & Inga marginata Wild. & Fabaceae \\
\hline Guamo macheto & Inga densiflora; L & Fabaceae \\
\hline Guamo rabo mono & Inga codonantha Pittier & Fabaceae \\
\hline Guanabana & Annona muricata L. & Annonaceae \\
\hline Guayaba & Psidium guajava; $\mathrm{L}$ & Myrtaceae \\
\hline Guayacan & Lafoensia acuminata (Ruiz \& Pav.) DC. & Lythraceae \\
\hline Jigua & Nectandra acutifolia $k$ (Ruiz \& Pav.) & Lauraceae \\
\hline Leucaena & Leucaena leucocephala; (Lam.) de Wit, & Fabaceae \\
\hline Limón Común & Citrus limon; L & Rutaceae \\
\hline Limón Mandarino & Citrus limonia; L & Rutaceae \\
\hline Limón rugoso & Citrus medica; L & Rutaceae \\
\hline Limón taiti & Citrus x latifolia; Tanaka ex Q.Jiménez & Rutaceae \\
\hline Mandarina & Citrus reticulata; Blanco & Rutaceae \\
\hline
\end{tabular}


Continuation Table 1.

\begin{tabular}{lll}
\hline Mango & Mangifera indica; L & Anacardiaceae \\
Mano de oso & Oreopanax incisus (Willd. ex Schult.) D. \& P. & Araliaceae \\
Matarratón & Gliricida sepium (Jacq.) Kunth ex Walp & Fabaceae \\
Moringa & Moringa oleifera; Lam & Moringaceae \\
Nacedero & Thichanthera gigantea (Humboldt \& Bonpland) & Acanthaceae \\
Naranja & Citrus x sinensis (L.) Osb. & Rutaceae \\
Níspero & Eriobotrya japonica (Thunb.) (tindl & Rosaceae \\
Nogal cafetero & Cordia alliodora (Ruiz \& Pav.) & Boraginaceae \\
Ovo & Spondias purpurea; L & Anacardiaceae \\
Pelotillo & Viburnum pichinchense Benth. & Caprifoliaceae \\
Pichuelo & Senna pistaciifolia (Kunth) H.S. Irwin \& Barneby & Fabaceae \\
Pino & Pinus patula Schltdl. \& Cham. & Pinaceae \\
Pomo & Syzygium jambos L. & Myrtaceae \\
Quillotocto & Tecoma stans (L.) Juss. ex Kunth & Bignoniaceae \\
Roble & Quercus humboldtii Kotschy ex A. DC. & Fagaceae \\
Samán & Samanea saman; (Jacq.) Merr. & Fabaceae \\
Sauce llorón & Salix humboldtiana; Willd & Salicaceae \\
Sauco & Sambucus nigra L. & Caprifoliaceae \\
Tomate de árbol & Solanum betaceum; Cav. Anales Hist & Solanaceae \\
Toronja & Citrus maxima (Burm. ex Rumph.) Merr. & Rutaceae \\
Tulipan & Spathodea campanulata; P. Beauv & Bignoniaceae \\
Urapan & Fraxinus chinensis; Roxb & Oleaceae \\
Vainillo (velero) & Senna spectabilis (DC.) H.S. Irwin \& Barneby & Caesalpiniaceae \\
Yarumo & Cecropia peltata; L & Urticaceae \\
Zapote & Pouteria sapota; L & Sapotaceae \\
\hline
\end{tabular}

In the three altitudinal ranges, a great similarity was found in the number of species, but not in the shared species; the range $<1500$ presented a value of 36 species; the range between 15001800, 35 species; and > 1800, 34 species. Of the woody species used in coffee farms, 32 are native and 27 are introduced; many of them have been naturalized, i.e. $45.8 \%$ are introduced woody species. These are used for different purposes; additionally, they have a number of ecosystemic functions such as: coffee shade, wood energy, soil protection, fodder, human food, and conservation of areas with environmental significance.

The Honduras Foundation for Agricultural Research - FHIA(for its initials in Spanish) (2004) indicates that the greatest number of species is found in low areas since coffee growers seek to control the high temperatures present in the production system. Farfán and Jaramillo (2009) mention that the presence of species for coffee shade decreases as the altitude increases. This fact is due to the increase in cloudiness, natural 
shade, since excess shade generates a decrease in production. In the present research, the number of species does not fluctuate depending on altitude; this study took into consideration the cultural importance of the species, and in addition to the species used as shade for coffee, trees in the different agro-ecosystems of the coffee farm were also considered.

The similarity of tree species found in the three altitudinal ranges in coffee production systems (Table 2) was evaluated using the Jaccard Index (JI); a low similarity was found between the altitudinal ranges. The highest value was found in ranges I and II because they shared 24 species, equivalent to $33.8 \%$ of their floristic composition. On the other hand, ranges I and III had a lower similarity level of $24.2 \%$, sharing 17 species.

The low similarity between altitudinal ranges can be attributed to climatic conditions and management; DaMatta and Rodriguez (2007) indicate that the variability of species diversity is due to climatic and edaphic conditions. The values found in the present study are considered low in comparison to those recorded by Villavicencio and Valdez (2003) for the rustic coffee agroforestry system (SAF for its initials in Spanish) and the medium sub evergreen forest (SMSP for its initials in Spanish) in San Miguel, Veracruz, (Mexico), which shared $58 \%$ of the woody species.

The dissimilarity found is possibly due to the specific way in which coffee growers manage the crop depending on the zone. How they handle the crop depends on the knowledge they have on the matter, which is largely empirical and based on customs (Escobar et al., 2016). Therefore, it is considered that each altitudinal range displays different customs, and all of these elements are evident in the management of the coffee farm.

Muñoz and Villota (2014) indicate that similarity is high when the species are native to the region, or the areas where they are located have similar geographical features. This research confirms what Muñoz and Villota (2014) state, as it showed that $45.8 \%$ of the woody species used in coffee farms are introduced, with a predominance of fruit trees.

To determine the Cultural Importance Index (CI), the following variables were considered: intensity of use, frequency of citation, and use value of each of the species found within the altitudinal ranges assessed in this study.

Table 2. Jaccard Index (JI) for three species in three altitudinal ranges in coffee production systems, municipality of La Unión, Nariño.

\begin{tabular}{lccc}
\hline \multicolumn{4}{c}{ Jacard Index } \\
\hline $\begin{array}{c}\text { Ranges } \\
\text { (m a.s.l) }\end{array}$ & $\begin{array}{c}\text { I } \\
(<\mathbf{1 5 0 0 )}\end{array}$ & $\begin{array}{c}\text { II } \\
\mathbf{( 1 5 0 0 - 1 8 0 0 )}\end{array}$ & $\begin{array}{c}\text { III } \\
\mathbf{( > 1 8 0 0 )}\end{array}$ \\
\hline I $(<1500)$ & 1 & & \\
II $(1500-1800)$ & $33.8 \%$ & 1 & \\
III $(>1800)$ & $24.2 \%$ & $26 \%$ & 1 \\
\hline
\end{tabular}


The assessment of woody species concerning altitudinal ranges (Table 3) showed that at altitudes $<1500 \mathrm{~m}$ a.s.l., I. densiflora and $T$. gigantea are the species with the highest values of intensity of use (4.41\%). In terms of frequency and use value, $C$. sinensis and T. gigantea stand out with percentages of 12.87 and $22.73 \%$, respectively. In range II (1500-1800 $\mathrm{m}$ a.s.l.), the species $I$. densiflora and $C$. reticulata stand out with $4.08 \%$ of intensity of use. Likewise, the species $C$. sinensis is the most important regarding use value and frequency of citation. At altitudes $>1800 \mathrm{~m}$ a.s.l., I. densiflora stands out for having the highest intensity of use (5.45\%) and use value $(24.95 \%)$. On the other hand, the species $\mathrm{P}$. americana is the most mentioned in this altitudinal range.

Based on the perception of coffee growers, the woody species above are of particular interest due to their multiple uses; they can be used as firewood, erosion regulators, remedies, and human and animal food. The findings are in line with those reported by Paz and Torres (2017), who state that among the useful flora of coffee plantations, edible and medicinal plants stand out; these contribute to satisfy the primary needs of man such as food and health.

The preference for certain woody species, especially those associated with coffee farming, is in line with research conducted in different coffee regions. Salamanca (2017) reported that coffee growers prefer the genus Inga as shade species, including $C$. sinensis, $C$. odorata, P. americana, P. guajava. These species provide suitable conditions for the crop; they generate higher productivity and provide food for wildlife and humans. In addition, they generate external products to be used as wood, firewood, green manure, and fruit, among others.

Table 3. Cultural importance of woody species in the three coffee altitudinal ranges, municipality of La Unión, Nariño.

\begin{tabular}{clllll}
\hline Ranges (m a.s.l.) & \multicolumn{1}{c}{ Species } & IU\% & FC\% & UV\% & CI\% \\
\hline & Thichanthera gigantea & 4.41 & 11.06 & 22.73 & 12.73 \\
& Citrus X sinensis & 3.52 & 12.87 & 14.86 & 10.42 \\
I & Inga densiflora & 4.41 & 9.12 & 11.48 & 8.33 \\
& Cordia alliodora & 2.64 & 0.77 & 19.54 & 7.65 \\
& Persea americana & 3.96 & 8.84 & 9.48 & 7.43 \\
\hline \multirow{2}{*}{ II } & Citrus sinensis & 3.27 & 13.97 & 14.30 & 10.51 \\
& Inga densiflora & 4.08 & 11.00 & 12.27 & 9.12 \\
& Thichanthera gigantea & 3.27 & 7.14 & 11.33 & 7.24 \\
& Citrus reticulata & 4.08 & 6.64 & 6.87 & 5.86 \\
& Lafoensia acuminata & 3.67 & 2.48 & 11.38 & 5.84 \\
\hline III & Inga densiflora & 5.45 & 16.02 & 24.95 & 15.47 \\
& Persea americana & 4.46 & 17.18 & 17.73 & 13.12 \\
& Citrus sinensis & 4.46 & 13.80 & 14.89 & 11.05 \\
& Trichanthera gigantea & 4.46 & 7.80 & 19.29 & 10.51 \\
& Eucalyptus globulus & 2.48 & 2.00 & 20.20 & 8.23 \\
\hline
\end{tabular}


On the other hand, Zapata (2019) mentions that species C. sinensis, I. edulis and C. alliodora were the most ecologically significant species in the coffee plantations of the municipalities of Pacho, Rioseco and Tibacuy in Cundinamarca. This importance would be related to the preferences of coffee growers regarding the use and characteristics of the species that have beneficial interactions with coffee, in addition to the fact that the most important uses of these species are as firewood and shade.

Regional studies on biodiversity in coffee growing areas of Colombia (Sánchez et al., 2013) indicate that the species most frequently used as shade in conventional coffee plantations in Santander was I. edulis with 28\%; as for the Cairo region, it was I. codonantha with $73 \%$, with the genus Inga predominating in the areas assessed.

In the coffee landscape of the municipality of La Unión, the use of woody species as shade for coffee farming is commonplace. As stated by Martinez et al. (2007), in some of the coffee farms of this municipality, shade is provided by commercially important species such as $C$. sinensis, C. reticulata and P. americana (avocado). One of the reasons that accounts for this is the fact that they generate additional income for the grower. However, other species such as Inga sp, G. sepium and A. acuminata, which are not considered commercially important, are also used to provide shade.

The cultural importance of the woody species present in the coffee farms was determined by the sum of the intensity of use (IU), frequency of citation (FC) and use value (UV) as indicated in Table 4. In the municipality of La Unión, the species I. densiflora had the highest percentage in relation to the sum of cultural importance in the three altitudinal ranges, with $32.92 \%$, followed by $C$. sinensis with $31.98 \%$, and $T$. gigantea and P. americana with $30.49 \%$ and $26.27 \%$ respectively. These findings reflect the importance of the use of woody species, especially as shade for coffee cultivation, land delimitation, soil protection, and human and animal food, which contributes to food security of the populations.

Studies carried out in different coffee growing regions validate the above, especially when it comes to species of the genus Inga. These species are particularly relevant due to their usefulness as shade for coffee farming and the fact that they provide organic matter to the soil, about 2.5 times more than in crops with free sun exposure. This contributes to the improvement of the physical characteristics of the soil, such as humidity and bulk density, which favor the development of coffee (Cardona and Sadeghian, 2005).

Cardona et al. (2013) and Farfán et al. (2013) state that guamo has been widely used as a shade tree for perennial crops, especially alongside coffee. The species I. densiflora and $I$. edulis are the most commonly used due to the multiple services they offer such as acting as a windbreak barrier, regulating solar radiation, controlling temperature, and reducing water demand. In addition, guamo is planted for its socioeconomic and ecological value; its wood is a source of firewood, which can be used in construction and carpentry, and its fruits are suitable for human and wildlife consumption. 
Table 4. Cultural Importance Index (CI) of woody species in coffee farms in three altitudinal ranges, municipality of La Unión (Nariño).

\begin{tabular}{|c|c|c|c|c|c|}
\hline \multirow{2}{*}{$\begin{array}{c}\text { Species } \\
\text { Scientific name }\end{array}$} & \multicolumn{3}{|c|}{ Altitudinal range ( $m$ a.s.l.) } & \multirow{2}{*}{$\% \mathrm{CI}$} & \multirow{2}{*}{$\begin{array}{c}\text { Ranking } \\
\text { CI }\end{array}$} \\
\hline & (I) $<1500$ & (II)1500-1800 & (III) $>1800$ & & \\
\hline Inga densiflora & 8.33 & 9.12 & 15.47 & 32.92 & 1 \\
\hline Citrus sinensis & 10.42 & 10.51 & 11.05 & 31.98 & 2 \\
\hline Thichanthera gigantea & 12.73 & 7.24 & 10.51 & 30.49 & 3 \\
\hline Persea americana & 7.43 & 5.72 & 13.12 & 26.27 & 4 \\
\hline Citrus reticulata & 6.82 & 5.86 & 5.14 & 17,81 & 5 \\
\hline Psidium guajava & 6.00 & 5.37 & 5.07 & 16.44 & 6 \\
\hline Cordia alliodora & 7.65 & 4,59 & 2.94 & 15.8 & 7 \\
\hline Mangifera indica & 6.93 & 5.56 & 1.79 & 14.27 & 8 \\
\hline Citrus limon & 3.85 & 7.37 & 2.62 & 13.84 & 9 \\
\hline Eucalyptus globulus & & 2.96 & 8.23 & 11.19 & 10 \\
\hline Ochroma pyramidale & 3.51 & 3.47 & 3.95 & 10.93 & 11 \\
\hline Lafoensia acuminata & 2.09 & 5.84 & 2.52 & 10.45 & 12 \\
\hline Erythrina edulis & 0.70 & 5.21 & 2.98 & 8.89 & 13 \\
\hline Inga codonantha & 4.18 & 3.63 & & 7.81 & 14 \\
\hline Cecropia peltata & 1.60 & 3.31 & 2.55 & 7.46 & 15 \\
\hline Citrus x latifolia & 2.28 & 4.38 & & 6.66 & 16 \\
\hline Erythrina poeppigiana & 5.58 & 0.71 & & 6.29 & 17 \\
\hline Citrus medica L. & 2.51 & 3.57 & & 6.08 & 18 \\
\hline Eriobotrya japonica & & 3.45 & 2.61 & 6.05 & 19 \\
\hline Inga marginata & 2.91 & 2.97 & & 5.88 & 20 \\
\hline
\end{tabular}

Similarly, the coffee growers surveyed in this study mentioned that $C$. sinensis is a fruit species intentionally planted in coffee farms; it has been one of the crops with the highest production in this area for many years due to family tradition and also the well-established production system. This fruit is regularly consumed by the inhabitants of the region, and it is also traded in the local markets, constituting a strategy for the diversification of the farms. In this sense, Rice and Ward (1997) indicate that the diversification of the coffee farms plays an important economic and social role; on one hand, it represents an additional income for the families, and it is used for self-consumption as well. On the other, it contributes to the improvement of the quality of the coffee (Saito, 2004; Sosa et al., 2004).

Based on the perceptions and local knowledge of the coffee growers, the tree species $T$. gigantea is culturally important for several reasons: It is used as animal fodder, especially for smaller species; it protects and controls erosion; it has medicinal uses; it improves coffee cultivation when grown alongside this crop. Ricaurte et al. (2014) mention other uses; 
the authors consider that this species maintains soil moisture, provides insulation through the natural fall of foliage, and reduces the loss of eroded soil (Garzón and Libreros, 1999).

Finally, Rice (2008) and Vargas et al. (2012) mention that farmers have a preference for trees because they are important for the livelihoods of rural populations. Trees can be used as firewood, wood, and food. In short, they have a positive impact on the family economy and help mitigate the negative effects of global climate change, offering greater resilience to the changes generated and mitigating their negative effects on the environment.

\section{CONCLUSIONS}

There exists a variation in the presence of woody species commonly used in coffee agroecosystems, especially as shade for coffee cultivation, between altitudinal ranges. This variation is due to the characteristics of each location; these include climate, temperature, type of system and soil fertility, moisture content, and other environmental factors such as solar brightness, cloudiness. In addition to the above, empirical or traditional knowledge of coffee growers regarding the implementation of woody species associated with the coffee systems of the region also influence such variation.

The richness of species found was high for each altitudinal range. This finding indicates that coffee growers handle diverse species, preferably for coffee shade in order to improve the quality of the product and the durability of the crop. Without the shade provided by these species, there is a risk that the coffee will burn due to the high temperatures present in the region; besides, the life cycle of the crop will be shorter and the input used for production will also increase.

When studying the cultural importance of woody species, considering the intensity of use, frequency of citation, and use value, the results showed that I. densiflora, C. sinensis, T. gigantea, and P. americana were the most important species for coffee growers in the region. The reasons that account for these findings are their ecological and socioeconomic value, since they provide additional income through the production of fruit and wood and are also fundamental to the sustainability of the production system.

Acknowledgements: The authors thank Universidad de Nariño, the Department of Nariño, and the Sistema General de Regalías (general royalty system) for financing the project.

\section{CONFLICT OF INTEREST}

The authors declare that there is no conflict of interest.

\section{BIBLIOGRAPHIC REFERENCES}

Alcaldía Municipal de La Unión. (2012). Plan de desarrollo municipal "La esperanza de un pueblo". Nariño: Alcaldía Municipal de La Unión. 142p.

Cardona, A.; Prado, Y.; Morales, S. (2013). Manejo de frutos y semillas de las especies forestales Inga densiflora Benth. e Inga edulis Mart. asociadas a paisajes cafeteros del departamento del Quindío. Revista de Investigaciones Universidad del Quindío. 24(2): 280-292.

Cardona, D.; Sadeghian, S. (2005). Beneficios del sombrío de guamo en suelos cafeteros. Avances técnicos Cenicafé. 334:120-178. 
Comité de Cafeteros de Nariño - La Unión. (2018). Comité departamental de Nariño. Informe Comité Departamentales, documento técnico. 92-103. Nariño: Comité de Cafeteros de Nariño.

DaMatta, F.; Rodríguez, N. (2007). Producción sostenible de cafetales en sistemas agroforestales del Neotrópico: una visión agronómica y ecofisiológica. Agronomía Colombiana. 25(1): 113-123.

Da Silva, V. A; Andrade, L.D.H.C; De Albuquerque, U.P. (2006). Revising the Cultural Significance Index: the case of the Fulni-ô in Northeastern Brazil. Rev. Field Methods. 18(1): 98-108.

Escobar, H; Lagos, T; Bacca, T.; Muñoz, J. (2016). Caracterización de los sistemas productivos de café en Nariño, Colombia. Revista U.D.C.A Actualidad \& Divulgación Científica. 19(1): 105113

Farfán, F. (2012). Árboles con potencial para ser incorporados en sistemas agroforestales con café. Chinchiná: CENICAFÉ. 87 p.

Farfan, V.; Jaramillo, R. (2009). Sombrío para el cultivo del café según la nubosidad de la región. Avances Técnicos Cenicafé. 379:1-8.

Farfán, F.; Mestre, A. (2013). Manejo del sombrío y fertilización del café en la zona central colombiana. Avances Técnicos Cenicafé. 331.

Farfán, F;; Baute, J.; Sánchez, P.; Menza, H. (2013). Guamo santafereño en sistemas agroforestales con café. Avances Técnicos Cenicafé. 396: 1-8.

FNC-Federación Nacional de Cafeteros de Colombia. (2018). Informe de gestión 2018, rentabilidad- legitimidad y resiliencia. Retrieved from https://federaciondecafeteros.org/app/ uploads/2019/10/Informe_Gestion_2018_ compressed-1.pdf

FNC - Federación Nacional de Cafeteros de Colombia. (2014). La política cafetera 2010 - 2014. Retrieved from https://www.federaciondecafeteros.org/ static/files/1La_politica_cafetera_2010- 2014. pdf

FNC - Federación Nacional de Cafeteros de Colombia.
(2020). Comportamiento de la industria cafetera colombiana 2020. Retrieved from https://www. federaciondecafeteros.org/static/files/Informe_ Industria_2020.pdf

FHIA - Fundación Hondureña de Investigación Agrícola. (2004). Guía práctica: Producción de café con sombra de maderables. Retrieved from http://www.fhia.org.hn/dowloads/ cacao_pdfs/ gpcafeconsombramaderables.pdf

Finol, H. (1971). Nuevos parámetros a considerar en el análisis estructural de las selvas vírgenes tropicales. Revista Forestal Venezolana. 14(21): 29-42.

Garen, E. J.; Saltonstall, K; Slusser, J. L.; Mathias, S.; Ashton, M.S; Hall, J.S. (2009). An evaluation of farmers' experiences planting native trees in rural Panama: implications for reforestation with native species in agricultural landscapes. Agroforestry Systems. 76(1): 219-236.

Garzón, H.; Libreros, H. F. (1999). Productividad forrajera, pérdida de suelo y escorrentía superficial bajo bancos protéicos de madre de agua (Trichanthera gigantea), sólo y asociado con chachafruto (Erythrina edulis) y/o mani forrajero (Arachis pintoi) en la Martinica alta. Ibagué, Tolima, Colombia. Bogotá: AGROSAVIA.

Gómez, L.; Caballero, A.; Baldión, J. (1991). Ecotopos cafeteros de Colombia. Bogotá: Federación Nacional de Cafeteros - FNC, 131 p.

MADR - Ministerio de Agricultura y Desarrollo Rural. (2017). Principales Cultivos por Área Sembrada en el Año 2014. Evaluaciones Agropecuarias Municipales. Retrieved from http://www. agronet.gov.co/Documents/Nari\%C3\%B1o.pdf.

Martínez, M.; Evangelista, V.; Basurto, F.; Mendoza, M.; Cruz-Rivas, A. (2007). Flora útil de los cafetales en la Sierra Norte de Puebla, México. Revista mexicana de biodiversidad. 78(1): 15-40.

Martínez, F. (2004). El suelo y la producción de cafés especiales. Investigación en temas del café. La Unión, Nariño: Cooperativa de Caficultores del Norte. 10p.

Muñoz, S.; Villota, T. (2014). Evaluación de macrofauna y composición florística en 
sistemas productivos de café (Coffea arabica L.) en el municipio de La Unión, Nariño. Pasto: Universidad de Nariño.

Murray, R.; Larry, J. (2005). Estadística. 4 ta edición ed. México, DF: Mc Grawill.

Oberthür, T.; Läderach, P.; Posada, H.; Fisher, M.; Samper, L.; Illera, J.; Jarvis, A. (2011). Regional relationships between inherent coffee quality and growing environment for denomination of origin labels in Nariño and Cauca, Colombia. Food policy. 36(6): 783-794.

Ordoñez, H. (2014). Estudio de la sustentabilidad de los sistemas de producción de café mediante indicadores, en el municipio de La Unión Nariño. Palmira, Colombia: Universidad Nacional de Colombia. 170p.

Paz, F.; Torres, R. (2017). Estado Actual del Conocimiento del Ciclo del Carbono y sus Interacciones en México: Síntesis a 2017. Serie Síntesis Nacionales. Texcoco, Estado de México, México: Programa Mexicano del Carbono en colaboración con el Centro de Investigación Científica y de Educación Superior de Ensenada y la Universidad Autónoma de Baja California.

Ricaurte, L.; Wantzen, K.; Agudelo, E.; Betancourt, B.; Jokela, J. (2014). Participatory rural appraisal of ecosystem services of wetlands in the Amazonian Piedmont of Colombia: elements for a sustainable management concept. Wetlands ecology and management. 22(4): 343-361.

Rice, R. (2008). Agricultural intensification within agroforestry: The case of coffee and wood products. Agriculture, Ecosystems and Environment. 128: 212-218.

Rice, R.; Ward, J. (1997). El café, la conservación ambiental, $y$ el comercio en el hemisferio occidental. Washington, DC: Centro de Aves Migratorias (SMBC) y Consejo para la Defensa de los Recursos Naturales (NRDC). 51p.

Saito, M. (2004). Sustainable coffee production. In: Wintgens, J.N. Coffee: growing, processing, sustainable production. pp.384 - 390. Weinheim: Wiley - UCH.
Salamanca, L. A. (2017). Evaluación de la producción de café bajo sombra con especies arbóreas en el municipio de pajarito. Retrieved from https://repository.unad.edu.co/ handle/10596/13725?show=full

Sánchez, L.; Durán, S.; Vélez, J.; García, R.; Botero, J. (2013). Estudios regionales de biodiversidad en las zonas cafeteras de Colombia. Cenicafé. 378: 1-8.

Sánchez, Y.; Tapia, M.; Salazar, J. (2017). Importancia cultural de vegetación arbórea en sistemas ganaderos del municipio de San Vicente del Caguán, Colombia. Revista UDCA Actualidad \& Divulgación Científica. 20(2): 393-401.

Sosa, L.; Escamilla, E.; Díaz, C. (2004). Organic coffee. In: Wintgens, J. Coffee: Growing, processing, sustainable production. A guidebook for growers, processors, traders and researchers. p. 339-354. Germany: WILEY-VCH Verlag GmbH \& Co. KGaA. doi: 10.1002/9783527619627

Tropicos. (2021). Missouri Botanical Garden. Retrieved from https://tropicos.org

Turner, N. (1988). The importance of a rose. Evaluating the cultural significance of plants in Thompson and Lilloet Interior Salish. American Anthropologist. 90(2): 272-290.

Universidad Nacional de Colombia. (2020). Scientific Collections OnLine. Biovirtual. Retrieved from http://www.biovirtual.unal.edu.co

Vargas, L.; Suárez, J; Pantoja, C. (2012). Conocimiento local de los servicios ecosistémicos en arreglos agroforestales de café (Coffea arabica L.) del sur de Colombia. Ingenierías \& Amazonia. 5(1): 17-29.

Villavicencio, L.; Valdez, J. (2003). Análisis de la estructura arbórea del sistema agroforestal rusticano de café en san miguel, Veracruz, México. Revista Agrociencia. 37(4): 413-423.

Zapata, P. (2019). Composición y estructura del dosel de sombra en sistemas agroforestales con café de tres municipios de Cundinamarca, Colombia. Ciencia Forestal. 29(2): 685-697. 